\title{
National Rural Employment Guarantee as Social Protection
}

\author{
D. Narasimha Reddy, Rukmini Tankha, C. Upendranadh and \\ Alakh N. Sharma
}

\begin{abstract}
This article is an attempt to highlight issues around the implementation of NREGA with a focus on its institutions, governance and innovations. The main proposition considered is that institutions and governance play an important role in determining the functioning of NREGA, and the trajectory of its success. The attempt is to identify the conditions for success (or failure) in the process, to draw lessons for mid-course corrections to the programme. This includes examining political, administrative and bureaucratic dynamics that may ensure better realisation of the 'right to work'. Based on a field study in three Indian states, it was found that differential impacts and achievements of the NREGA are related to variations in the commitment of local leadership, levels of institutional preparedness and governance capacities. The experience of these states offers certain insights which may help improve implementation policy of the NREGA.
\end{abstract}

\section{Introduction \\ India's guaranteed public employment programme (NREGP) ${ }^{1}$ is one of the largest social protection programmes enacted in recent times, and has attracted attention around the world for its approach, content, design and implementation mechanisms. The programme is founded partly on economic considerations, including the goal of full employment (Bhaduri 2005) and stimulation of demand during the periods of economic contraction. It also represents an effort to cushion the negative effects of globalisation, especially through the creation of wage employment and assets in rural areas. From the perspective of a realpolitik it has placed development at the centre of the country's grassroots democratic processes (IHD 2008). It is also viewed as a precursor to an inclusive development paradigm (NCEUS 2009). \\ 1.1 NREGS: programme features ${ }^{2}$ \\ The NREG is based on the twin principles of universality and self-selection. First, it offers the legal right to work for those who demand it within a timeframe ( 15 days of applying for work) at a guaranteed minimum wage. Second, the universal nature of the programme eliminates targeting errors. The process of}

implementation and community involvement (in the form of planning of works and social audits) is expected to reduce the corruption and malpractice that were an important weakness of earlier programmes.

Informed as it is by the basic elements of rights and entitlements, the immediate objective of the NREGS is to provide work that supports and augments the income of needy households to overcome deprivations. There are also expectations that in the long term, it offers a four-fold 'transformational' potential, through 'multiplier accelerator synergy', allowing simultaneously for (1) ecological transformation; (2) transformation of sustainable livelihoods; (3) technological transformation, and most importantly; (4) democratic transformation of rural governance structures informed by the notions of citizenship and entitlements (Shah 2009a). The implementation process of NREGS is expected to unleash transformative potential in both social relations and rural governance (see also Shah 2009b,c), for example through works such as the development of SC/ST households' land.

IDS Bulletin Volume 41 Number 4 July 2010 @ 2010 The Authors. Journal compilation @ Institute of Development Studies Published by Blackwell Publishing Ltd, 9600 Garsington Road, Oxford OX4 2DQ, UK and 350 Main Street, Malden, MA 02148, USA 


\section{Box 1 Mismatch between job cards given to households and actual persons working}

Secondary data for scheme implementation in the financial year 2008-09 points to the fact that out of the total households given job cards, only about 37 per cent of households in Bihar were in fact provided employment under NREG. Similarly in Andhra Pradesh, the proportion of households actually working among those that were issued job cards was 53 per cent, while in Rajasthan the proportion was about 75 per cent (www.nrega.nic.in). Other households, according to officials, merely hoarded the job cards as security in anticipation of receiving unemployment allowance. Since NREG is based on self-selection, there is no restriction on the distribution of job cards. Several households without members willing to do physical labour also acquired job cards in the hope of other benefits. Thus, households with job cards always exceed households with actual participation.

\subsection{Methodology}

Although NREG is a centrally sponsored programme, its implementation is bound to differ according to institutional contexts at the state level. The choice of the three states: Rajasthan, Bihar and Andhra Pradesh - was made in order to capture these contextual differences in implementation. Gram Panchayats (GP) are the institutions which are entrusted with the responsibility of implementation at village level. Other civil society and public institutions are also expected to play a supportive role. Although GPs are not very effective in Rajasthan, there have been active social mobilisation efforts, particularly by civil society bodies such as agricultural labour unions - Mazdoor Kisan Shakti Sangathan. The assumption is that the presence of such organisations promotes awareness among labourers of the NREGA and its entitlements and also institutional preparedness on the part of implementing agencies. Furthermore, the state has long experience in implementing public works programmes as a part of drought relief. In Andhra Pradesh too, the GPs are weak, but proactive bureaucracy, grassroots mobilisation through agencies such as self-help groups, the innovative use of IT for monitoring and mechanisms of transparency (social auditing) are critical factors in the implementation of NREG. In contrast to these two states, Bihar has neither strong GPs nor civil society organisations known for social mobilisation. These contrasting institutional contexts were expected to help in identifying critical factors in NREG's performance.

Based on the criterion of job creation which reflects the higher and lower ends at all levels, we decided to select two sample districts in each state, two sample blocks in each district, and eight sample panchayats in each block. In all, a total of 1,443 worker households spread equally across the three states were interviewed. Apart from these, focus group discussions were held with several groups of stakeholders, including Panchayati Raj Institution (PRI) leaders, officials at the panchayat, block and district levels. Worksite observation also formed part of the data gathering process.

This article is divided into four sections. The second and third sections provide evidence on the functioning of NREG from the perspective of processes, entitlements and institutional factors. The last section discusses policy implications of the findings.

\section{NREG process issues}

\subsection{NREG pre-work processes}

Given that the vast majority of the labouring poor have been exposed for the first time to demand-based public works programmes as a matter of right, the first step in implementation is creating awareness of the programme, which is followed by registering workers and providing them with job cards. This is followed by applications demanding work, which are acknowledged by issuing dated receipts. This entitles the workers to claim unemployment allowance if work is not provided within 15 days. Planning for, designing and allocating work are the major pre-work processes. Although in the initial period, the registration process was slow in Bihar due to a lack of effective awarenesscreating institutions, the number of households registering increased substantially later on. Also, although job cards with photographs are mandated to be issued free, about Rs20 (onequarter of a day's wage under NREG) for each card was collected as a bribe in Bihar. But such instances of payment for getting a job card have been rare in Andhra Pradesh and insignificant in 


\begin{tabular}{|c|c|c|c|}
\hline & Andhra Pradesh & Bihar & Rajasthan \\
\hline \multicolumn{4}{|l|}{ 'Application' mode } \\
\hline Yes & 71 & 22 & 91 \\
\hline No & 29 & 78 & 9 \\
\hline All & 100 & 100 & 100 \\
\hline \multicolumn{4}{|l|}{ Kind of 'application'* } \\
\hline Individual written application & 1 & 31 & 28 \\
\hline Individual informal request & 60 & 54 & 54 \\
\hline Collective written application & 4 & 7 & 10 \\
\hline Collective informal request & 35 & 7 & 8 \\
\hline All & 100 & $100^{* *}$ & 100 \\
\hline \multicolumn{4}{|l|}{ Receipt with date } \\
\hline Yes & 16 & 4 & 21 \\
\hline No & 84 & 93 & 77 \\
\hline Total & 100 & $100^{* *}$ & $100^{* *}$ \\
\hline \multicolumn{4}{|c|}{$\begin{array}{l}\text { Source IHD Survey (2009), pertaining to fieldwork conducted by IHD in April-July 2009. Fieldwork sample spanned } \\
3 \text { states - Andhra Pradesh, Bihar and Rajasthan, covering } 2 \text { districts in each state, } 2 \text { blocks in each district and } \\
8 \text { panchayats in each block. A total of 1,443 worker households were interviewed. }\end{array}$} \\
\hline
\end{tabular}

Rajasthan. The present position is that there are more households with job cards than people actually seeking work and working (see Box 1). This is because many households see the job card itself as a kind of entitlement, which they hope will help them in the future in case of any reservations for economically weaker groups (Pankaj and Tankha 2009).

\subsection{Worker entitlements}

Given the high level of illiteracy among work seekers, the demand for work by 'application' takes an informal turn. Table 1 provides certain basic facts about this informal process based on the response of those who actually secured work. The proportion 'applying' for work in Rajasthan is high (91 per cent) followed by Andhra Pradesh (71 per cent) but very low in Bihar (78 per cent). Even in Rajasthan and Andhra Pradesh, in most of the cases of 'applications' are informal, and are submitted via individual or collective requests rather than written applications. The formal 'application' takes the shape of filling out the proforma once the work has been assigned. The significance of this informality is partly due to illiteracy of work seekers and partly because the functionaries prefer to avoid paying unemployment allowance in case of failure to provide employment within 15 days of receiving each formal application.
From the supply side, a lack of projects, delays in the release of funds, lack of planning and the unavailability of technical staff appear to be some of the reasons for this situation. However, no instances of workers' claiming unemployment allowance (an entitlement in the event of a failure to provide jobs within 15 days) were found in the field. These are certain process deficits in this regard, with records of job requests and acknowledgement of demand for work being very poorly maintained by local authorities. Instances of non-provision or undated receipts at the time of demand for work were observed, suggesting that officials at the local level have been circumventing the provisions relating to unemployment allowance. This brings to the fore the issue that although NREG is a demanddriven programme, its effectiveness in the context of low literacy and poor awareness depends upon the proactive provision of continuous work through a group of welldesigned projects.

Another important aspect closely related to the provision of work is related to entries on the job cards of the workers regarding days worked and wages due. It was found that in only about onequarter of the cases were there complete entries made in the job card. Only partial entries were made in job cards across the three states - 
Andhra Pradesh in 32 per cent of cases, in Bihar in about 22 per cent of cases and in Rajasthan in about 66 per cent of cases (IHD 2009). Such a situation seriously violates the entitlements of workers and provides scope for corruption and other malpractices, as workers are not then in a position to contest any discrepancies in payments.

\subsection{Worksite facilities and muster rolls}

Under the NREG Act, it is mandated that certain worksite facilities must be in place to ensure proper conditions of work. These include four basic facilities: drinking water, shade, first aid kits and a crèche if there are six or more women with children below the age of five years. However, it was observed that the status of worksite facilities was uniformly poor across the three states studied. Almost none offered all these facilities. Drinking water was provided in some sites, shade in some places in Rajasthan and Andhra Pradesh, first aid in some places in Bihar and Andhra Pradesh, but there were crèches at only very few of the worksites visited. More surprising was that some of the basic implements for digging and carrying earth, and even vessels for drinking water were not provided in Bihar. There appeared to be no institutional mechanisms for accountability regarding these worksite facilities, which suggests a need for the development of benchmarks to ensure not only employment but decent work.

One important feature that ensures transparency is the muster roll (attendance sheet) to be marked by the officially appointed field worker and to be signed by the workers (with a thumbprint in the case of the illiterate). Ensuring proper maintenance of the muster roll is an important function of the field worker, as it forms the basis for the calculation of attendance and wages. On this front, gaps are found in Bihar, with only just over one-third of worksites reporting the use of muster rolls. In the majority of cases in this state (85 per cent), attendance is taken in an informal notebook, 'kachcha khata'. Also in both Bihar and Rajasthan, nearly half the sample workers did not sign the muster rolls at all and in the majority of cases these rolls were not kept up to date.

These deficiencies deny transparency and create room for tampering.

\subsection{Outreach and employment created}

An important indicator of the programme performance is the number of days of employment provided to a household (Table 2). Rajasthan enjoyed the highest number of person days of employment per household (76 days), followed by Andhra Pradesh (74). Bihar records the lowest number of days (24). Rajasthan and Andhra Pradesh also show that a majority of households ( 58 per cent and 53 per cent, respectively) get 75-100 days of employment.

An initial analysis of the sampled worker households confirms the scope of NREG as a social protection programme, reaching the most needy economic and social groups of the country. Those coming from landless or marginal farmer families, engaging in casual labour, belonging to economic groups below the poverty line (possessing a BPL card or card for the poorest), and hailing from the most deprived social groups (scheduled caste and scheduled tribes) constitute the majority of NREG workers (Table 2). These characteristics ${ }^{3}$ impose enormous responsibility on the implementing apparatus in terms of ensuring effective delivery. However, these very characteristics of the participating households may also create the conditions for misuse and neglect of processes, and therefore call for effective institutional and governance structures.

In Rajasthan, female participation in the scheme is much higher than male. This is due to outmigration by male members of the household, seeking higher wages and a longer duration of continuous work which NREG is not able to provide. In Andhra Pradesh, the relatively higher participation of women in NREGS is partly due to NREG wages being higher than market wages for women and partly because market wages for men in some agriculturally better-off pockets being higher than NREG wages. There are also instances where men prefer to migrate not only for higher wages but also for longer duration of work. NREG work is often in the nature of sporadic and short duration. Bihar, the reason for low participation of women in NREGS is not only the need to attend to domestic chores (59 per cent of respondents) but also severe cultural inhibitions on women's wage work among several castes. In Rajasthan, although women's participation is high, it would be more if adequate child care facilities at the worksite are provided.

There are several factors that contribute to the provision of employment upon demand. Receiving administrative and technical 


\begin{tabular}{|c|c|c|c|}
\hline & Andhra Pradesh & Bihar & Rajasthan \\
\hline Average no. of days of employment per household & 74 & 24 & 76 \\
\hline \multicolumn{4}{|c|}{ Share of employment by social and economic categories (\%) } \\
\hline \multicolumn{4}{|c|}{ Social group } \\
\hline $\mathrm{SC}$ & 45 & 69 & 33 \\
\hline ST & 5 & 7 & 23 \\
\hline $\mathrm{OBC}$ & 35 & 23 & 35 \\
\hline Others & 15 & 0 & 10 \\
\hline \multicolumn{4}{|l|}{ Gender } \\
\hline Male & 49 & 71 & 28 \\
\hline Female & 51 & 29 & 72 \\
\hline \multicolumn{4}{|l|}{ Economic status (ration card type) } \\
\hline Above poverty line & 3 & 11 & 49 \\
\hline Below poverty line & 89 & 40 & 35 \\
\hline Antyodaya card (very poor) & 7 & 36 & 11 \\
\hline Annapoorna card (destitute/old age) & 0 & 1 & 1 \\
\hline Others & 1 & 12 & 4 \\
\hline \multicolumn{4}{|l|}{ Land category } \\
\hline Landless & 22 & 80 & 20 \\
\hline Marginal & 48 & 19.50 & 67 \\
\hline Small & 24 & 0.41 & 9 \\
\hline Medium & 5 & 0 & 3 \\
\hline Large & 0 & 0 & 1 \\
\hline
\end{tabular}

Source IHD Survey (2009), pertaining to fieldwork conducted by IHD in April-July 2009. Fieldwork sample spanned 3 states - Andhra Pradesh, Bihar and Rajasthan, covering 2 districts in each state, 2 blocks in each district and 8 panchayats in each block. $A$ total of 1,443 worker households were interviewed.

sanctions, planning, fund release, weather conditions, and agricultural seasons play an important role in number of days of employment created. Often there appears to be mismatch between employment need and availability, a mismatch that would also affect overall participation rates. Workers' preference in all regions is for longer duration of work without too many breaks. But in reality, shorter duration and frequent breaks are usual and both discourage participation and encourage migration seeking continuous work for longer period.

\subsection{Wage determination and level of wages}

One of the important dimensions of right to employment is that workers are entitled to payment of wages commensurate to the minimum wages of the relevant states. Wages are to be paid within 15 days of completion of work, failing which the officials concerned are liable for punishment.

In all states except Himachal Pradesh, wage payments are supposed to be made on the basis of a piece rate linked to the 'Schedule of Rates' converted to a minimum wage rate.

While almost all respondents reported that wage payment was made on the basis of work measurement in Andhra Pradesh and Rajasthan, in Bihar about half the respondents said they were paid a daily rate which implies that work measurements are not taken seriously. Also, while in Andhra Pradesh and Rajasthan, workers reported having seen officials measuring work, in Bihar, 17 per cent of households reported that they had not seen officials doing so. This discrepancy exposes a lack of knowledge among workers about the basis of their wages, and also approximations and deficiencies in measuring of work by technical staff, who in turn complain of inadequate staffing (Box 2).

Issues of division of work at worksites, work output and work measurement and the payment of corresponding wages for the work done needs greater clarity, as was especially brought to the fore in Rajasthan. For instance, time-motion-and- 
Box 2 Wage determination and work measurement issues in group-based work

A peculiar problem was observed in Rajasthan. Usually large numbers of workers were present at worksites, up to 50-70 persons, and they were further divided into teams to undertake tasks (see also Khera 2008). Gender and caste-related issues surfaced in some cases. It was found that only some members of the group worked, while others shirked, assuming they would be paid anyway. As a result of this, we found 70-year-olds and even some college students at the worksite during their summer holidays, not undertaking work but merely hanging around. In Tonk district, we found some people playing cards at the worksite. Moreover, members of dominant communities such as Gujjar and Jat did not work, but threatened associates and officials to mark their attendance so that they could claim wages.

But there is also evidence to the contrary. In Andhra Pradesh there were three instances where weak, elderly and female workers were allowed lighter tasks. Lactating mothers were also allowed to break in order to breastfeed. In these cases, wages were shared equally by consensus among the groups.

However, there were also cases where male labourers in a mixed group did not work hard, making women do much of the work, and leading to female labourers preferring to work without men in their groups. The programme officer in charge of NREGA in Tonk District mentioned that they were experimenting by trying to make separate groups for males and females, but often this too was not preferred.

One of the reasons for low daily wages in Rajasthan is crowding at worksites. In one instance in Nadri Panchayat of Tonk District, an area with hard soil and rock, after the division of wages among workers, only Rs 1 per day accrued to each of them due to the large number of workers, suboptimal work output and the outdated schedule of rates (SOR), specifying the amount of work to be completed to earn minimum wages. On the contrary, in another village where the numbers of 'sitting' labourers were few in number, wages were above Rs80.

work studies conducted in Andhra Pradesh found that labourers had to work almost three times longer under the standard Schedule of Rates (SOR) to get the basic minimum wage, owing to the observed difference between the wage promised and the actual wage received by the worker under the task rate formula (CSE 2008: 33-5). Based on the recommendations of this study, the Andhra Pradesh government issued orders in April 2007 modifying the wage entitlements of workers in various NREGA works. In October 2008, Bihar too adopted a new schedule of rates based on time and motion studies which was considered to be more genderfriendly. But in practice, there have been several approximations made undoing the considerations of productivity norms. Considerable delays in the payment of wages in Rajasthan are attributable to measurement delays.

As a result, the effectiveness of the piece-rate method is being reconsidered, and suggestions have been made to de-link wages from output and instead, to pay daily wages in order to simplify processes. Links between the mode and frequency of wage payment also need to be explored to minimise delays in payment to NREG workers and, depending on the handling capacities of banks and post offices, these institutions may be seen as a pivotal mechanisms in reducing such delays.

In all the three states studied, NREG minimum wages for women are higher than rural agricultural and non-agricultural market wages. In Bihar and Rajasthan NREG minimum wages for male workers are also higher than prevailing market wages in agriculture. However, in Rajasthan non-agricultural market wages in urban areas are higher. In Andhra Pradesh, in many agriculturally prosperous districts, male agricultural market wages are higher than the NREG minimum wages. These wage differences also influence the extent of male and female participation in NREG employment. 


\begin{tabular}{llll}
\hline Table 3 Nature of NREGS works undertaken (\% share of each type) & & \\
\hline Type of work & Andhra Pradesh & Bihar & Rajasthan \\
\hline Water conservation & 11 & 0 & 0 \\
Drought proofing & - & 3 & 2 \\
Irrigation works & - & 7 & 3 \\
Irrigation on individual land & 15 & 0 & 3 \\
Renovation of traditional water bodies & - & 10 & 30 \\
Land development & 45 & 3 & 2 \\
Flood control & - & 10 & 0 \\
Rural connectivity & - & 65 & 57 \\
Other works* & 29 & 2 & 3 \\
Total & 100 & 100 & 100
\end{tabular}

*Other works include silt application, percolation tanks, earthen bunding, etc.

Source IHD Survey (2009), pertaining to fieldwork conducted by IHD in April-July 2009. Fieldwork sample spanned 3 states - Andhra Pradesh, Bihar and Rajasthan, covering 2 districts in each state, 2 blocks in each district and 8 panchayats in each block. $A$ total of 1,443 worker households were interviewed.

\subsection{Process of work selection, planning and type of NREG works}

It can be seen that most works undertaken in Andhra Pradesh were land development works (45 per cent), with other works (29 per cent). ${ }^{4}$ In Bihar, most are rural road connectivity works (65 per cent), while a few involve the renovation of traditional water bodies and irrigation works (Table 3). In Rajasthan similarly, most involve rural road works. Some renovation of traditional water bodies was also being undertaken, mostly in Tonk, Rajasthan.

The process of selection of works is meant to be participatory and the works selected should reflect local development needs. The process involves Gram Sabha meetings in which members of the village community assemble to discuss and select the nature and location of works to be undertaken under NREG. Although different local level actors were reported to be present at the time of selection of works, suggestions from people as to what works to be taken up were not listened to, and it largely emerges that scheme selection ultimately comes 'from above', usually drawn from a previously used, ready-made shelf of works, resulting in ad hoc scheme selection. Further, a disturbing feature of some works in Rajasthan was the violation of the guidelines that labour cost should be at least 60 per cent of the project cost and the material cost should not exceed 40 per cent. In most of the works, the material cost was in the range of $60-80$ per cent. It is observed as a deliberate ploy to misappropriate by inflating the procured material cost.

The allocation of funds for NREG consists of three levels of works: at least 50 per cent of the funds are to be used by Gram Panchayat (taking up village level works), 30 per cent by Panchayat Samiti (taking up inter-Panchayat works) and the remaining 20 per cent by Zila Parishad (taking up inter-block works). A slew of administrative sanctions and technical sanctions are also needed for the works to be passed, with the works employing a greater amount of funds needing sanction from correspondingly higher local level authorities. However, it was often found that proposals for some of these larger works languished in the offices of the higher level functionaries, awaiting their sanction, thereby delaying their commencement.

Effective planning of works is an important prerequisite for the quality of assets created through NREG. The shelf of projects may be expanded and works need to be prioritised, based on need rather than the limits of the implementing structures. The current approach of having limits to sanction works at various levels of the panchayat raj structure appears to be negatively affecting the quality of assets. 


\section{Box 3 Accountability through social audit in Andhra Pradesh}

In Andhra Pradesh, social audits have been instituted through a state-led initiative, and are conducted by an independent group - the Society for Social Audit, Accountability and Transparency (SSAAT), Department of Rural Development, Government of Andhra Pradesh. Social audits, as designed in the NREG, are intended to serve as a platform for the redress of grievances. The audit exercise involves public hearings which act as a forum for exposing discrepancies in government records of programme implementation. This occurs through the testimonies of workers and opportunities given to officials to publicly defend their actions (Aiyar and Samji 2009). As part of the social audit, state and district resource persons train village social auditors, who in turn are involved in monitoring and evaluating scheme processes. They also play a key role in raising awareness of beneficiaries through discussions and dialogue about the NREG programme and its provisions. The social audit as conducted in Andhra Pradesh has developed into a best practice in terms of public accountability, serving as a model to be replicated in all states. Audits have been conducted in 7,000 households in all 22 districts of the state, with the involvement of more than 150 NGOs and civil society organisations. As a result, there have been a number of instances of corrective action such as initiation of departmental enquiries, dismissal of erring officials due to malpractice and voluntary recovery of up to Rs30 million from NREG-related misdeeds (Rajsekhar 2009).

Bureaucratic hurdles in sanctions also need to be addressed. The development of lands belonging to scheduled castes and scheduled tribe households and other households below the poverty line appears to have tremendous potential in unleashing productive capacities in rural areas, wherein hitherto non-arable lands can come into cultivation, as the study found in Andhra Pradesh. Such works would also trigger a multiplier effect. It is imperative to identify and prioritise such works through a process of village-level resource planning. Mechanisms for the equitable benefit-sharing of assets also need to be developed, especially in cases such as land and water-related works, where in the postconstruction phase, benefits often accrue to landowners rather than the landless.

\subsection{Grievance redress mechanisms and accountability provisions}

Grievance redress mechanisms remain conspicuous by their absence at the district and sub-district levels, and through discussions with the NREG workers it emerged that this proves very costly for them, as they remain powerless in exposing scheme irregularities. Often, as was reported in numerous cases in Bihar, workers are at the mercy of locally powerful groups or actors, also in charge of scheme implementation (sometimes by misappropriation), who are able to manipulate scheme benefits to their gain. They interfered at the time of wage payment and siphoned cuts from the wages due to the workers.
However, the NREG workers could not turn to an independent third party to expose this infringement of the programme's rules. A recent amendment in the NREG Act has been made to rectify this situation, by providing a district ombudsman to look into NREG-related complaints.

In fact, other accountability mechanisms are built into the NREG programme such as social audits (Box 3); the demand for proactive disclosure of NREG-related documents through display boards or using the Right to Information Act; and public scrutiny of accounts, vigilance and monitoring committees to oversee the quality of implementation of the scheme, existed in theory but not in practice, except in Andhra Pradesh.

Punitive actions for addressing deficits in entitlements may need to be established in earnest. Such measures will enhance transparency as well as responsiveness among officials to check incomplete entries in job cards, measurement delays and delays in payment, which need to be purged. Additionally, instituting of a grievance redress agency or actor, independent of scheme stakeholders, would help in ensuring transparency. The establishment of district ombudsmen is a step in this direction. Social audit mechanisms, as instituted in Andhra Pradesh, can be replicated in other states, although attention is needed to ensure that such an exercise is adapted 
to local contexts, so that NREG workers can voice their grievances without fear.

\section{Institutions and governance in NREG implementation}

3.1 Awareness creation through NGOs and local level initiatives

While government functionaries recruited especially for the implementation of the NREG are expected to deliver their services, there is a host of other agencies involved at various stages of implementation. As a rights-based programme, NREG envisages certain prerequisites in terms of enhanced awareness and understanding of the nuances of rights and entitlements and the processes of their realisation. At this juncture, there still appears to be much scope for creating awareness systematically among all the stakeholders. Information dissemination about the Act, its provisions and entitlements, is necessary and appropriate processes are needed to ensure messages reach workers as well as implementing officials, Panchayat leaders and other important stakeholders. The Right to Information (RTI) has been invoked in some instances in Rajasthan and Andhra Pradesh as a corrective instrument to check corruption, where through demand for proactive disclosure of NREG-related documents by workers, leakages have been exposed.

Awareness of NREGA and its entitlements was created in Tonk District of Rajasthan by an NGO from Jaipur. Puppetry was used to communicate with workers about their rights and the details of the employment programme. In Udaipur, focus group discussions revealed that 'role-playing' as a method was also used to create familiarity among prospective workers, with the specifics of the scheme.

In Bihar, the role of NGOs and self-help groups (SHGs) in awareness creation about the programme is an exception. However, officials in the village of Dobhi, Gaya district, reported that the Gautam Budh NGO is creating awareness about NREGS, as is Jeevika, an SHG, in two or three villages of Purnia district. Additionally, villagers in Neema in Gaya district claimed that the local cadre of CPI (ML) was creating awareness among its members, who are now well informed about the NREGS. Few local officials said that mahila samitis (women's groups) were creating awareness among women.
Women's SHGs facilitated by the Indira Kranti Patham (IKP), a government-led poverty reduction and women's empowerment programme in Andhra Pradesh, play an important role in NREGS. SHG members and leaders and the cadre of community workers facilitate awareness, job card access and the work application process. Leaders of federations of SHGs at the Panchayat and Mandal levels and field workers also play important roles in facilitating payment transactions and social audits. Recently, a Memorandum of Understanding (MoU) was signed between the Department of Rural Development and a network of 13 NGOs in Anantapur district of Andhra Pradesh to facilitate the development of degraded common lands under NREG.

Thus, social mobilisation at the grassroots level appears to be a sine qua non for the effective realisation of rights. It was also found that wherever civil society agencies played the role of facilitators, there were more effective processes in place.

\subsection{Gram Sabhas}

The Gram Sabha of the village Panchayat is an important element in NREG's functioning. The Gram Sabha is meant to be instrumental in the planning of local need-based works under NREGS. Across the three states, about 44 per cent of respondents said that NREGS in particular was discussed in Gram Sabha meetings, although in Rajasthan this figure was small. Furthermore, as to whether NREGS works were selected at the Gram Sabha meetings, overall 40 per cent of respondents said that this did occur, again more so in Andhra Pradesh and Bihar than in Rajasthan.

The attendance and representation of different groups at the Gram Sabha also determines, to some extent, the types of assets that will be created, and in turn who will benefit most from that asset creation. For instance, most women in Bihar reported that they did not participate in the Gram Sabha as they did not understand much of what happened there. What is lacking is the comprehension of the overall role of the programme, which can only come through proper social mobilisation. Also, while the role of Gram Sabhas is envisaged at the time of social audit, it was observed that this was often not the case, with audits necessarily being driven by either 'top-down' or 'bottom-up' pressures. 


\section{Box 4 Grievances of NREG functionaries}

Interviews in Bihar revealed the following:

- At the Panchayat level in particular, Rozgar Sewaks received a consolidated salary of Rs3,000 per month, nearly a subsistence wage. Further, salaries for NREG personnel were often delayed by 3-6 months.

- Understaffing of functionaries at each level meant that they were often given additional charge of blocks or panchayats beyond their designated ones.

- Despite being appointed specifically for the NREG, officials complained of being burdened with non-NREG work such as preparing BPL lists and serving during election duty, resulting in less attention to NREG work.

- No travel allowance or transport facility was provided to them, despite their having to oversee multiple worksites, for which they had to cover their own expenses.

\subsection{System of monitoring of NREG works}

A web enabled monitoring and information system (MIS) has been initiated

(www.nrega.nic.in) in order to track the entire NREG implementation process, with the aim of inducing transparency by placing all relevant programme related information in the public domain.

Andhra Pradesh has taken this initiative a step further. While all other states have MIS developed by the National Informatics Corporation (NIC), Andhra Pradesh developed its MIS to suit the state's specific needs with the help of Tata Consultancy Services (TCS). This is modelled in a manner such that each mandal office has a client-server system, where all data and work/wage related entry is done by a computer operator. The system provides details regarding registration of wage-seekers, management of shelf of works, work progress, monitoring and payment, management of funds and shares reports and analysis. All the data from the blocks is later integrated at the state level. Each step in the implementation of the NREG is computerised, and data is updated on a daily basis, thereby allowing for 'real-time' monitoring, rather than aggregating data gathered over a period of a month as in the national MIS, which results in time lags and not being able to resolve problems as they arise. This allows for special mechanisms that flag anomalies such as workers without bank accounts and wage delays, and also automatically generates pay slips to workers for wage payment (Ngo 2010). The software has been designed to be worker-centric and offers the use of images and voice recognition to reach out to illiterate workers wanting to know their work and wage status.
In other states, however, filling in the MIS datasheets has proven difficult, in part owing to the lack of awareness of NREG functionaries of the practice, lack of personnel to conduct data entry, infrequent access to the internet at the block level for uploading the relevant information and yearly changes in formats. For instance, in Bihar, these detailed records are available only for the financial year 2008-09, although programme implementation has been ongoing in some districts since 2006.

Taking the example of Andhra Pradesh, the use of Information and Communication Technologies (ICTs) at various stages of NREG may be considered, for example in the identification of NREG workers and keeping records of their payments. Biometrics for attendance (as noted earlier), smart cards, handheld devices, electronic payments and appropriate tracking software represent steps in this direction, so that the need is to identify replicable processes for different institutional contexts.

\subsection{NREG functionaries}

At the three levels of local government representation - the district, the block and the panchayat, there are supposed to be dedicated NREG personnel, i.e. a District Programme Coordinator, a Block Programme Officer and a Panchayat Rozgar Sewak. These officials are responsible for the implementation of the programme at different levels. However, their abilities and effectiveness in delivering on their roles and responsibilities are crippled by inadequate staffing, ad hoc positions without any career prospects, poor salaries, a heavy workload and the absence of transport facilities or allowances (Box 4). 
Box 5 Cutting leakages - wage payment using ICT and biometric smart cards

An innovative feature of the NREG programme in Andhra Pradesh is wage payment through banks and post offices, with the use of ICT and transaction-based Monitoring and Information Systems (MIS). A strict payment cycle is supposed to be followed, with work measurement being completed by day 6 , after which preparation of cheques, the transfer of cash, and the final disbursement to post offices occurs by day 13, well within the stipulated 15 days for payment of wages.

Further, after a recent pilot study testing its efficiency, Financial Information Network and Operations Ltd (FINO), a technology solutions provider, is paying wages to NREGS workers through biometric smart cards (using fingerprint authentication) in 259 villages in five districts of Andhra Pradesh (93 in Karimnagar; 17 in Medak; 53 in Chittoor; 55 in East Godavari and 41 in Mahaboobnagar). This is aimed at reducing transaction time as well as costs to workers and also enabling transparent payments.

Lapses or delays on the part of the Junior Technical Engineers and Assistants in visiting worksites to chart and account for the work done by the labourers were found to translate into subsequent delays in the payment of wages to the workers. Problems also arose from the appointment process. For instance, the 'mate' at the village level in Rajasthan was often an appointment determined by the pressure of politically influential people, and it was reported that in many instances, corruption was mainly generated by these mates, who were connected with 'muscle' men.

Considerable time is spent by staff at the field level on procedures which need to be simplified. Technical support for field functionaries and panchayat representatives on the planning and monitoring of works is another important need at the field level. The absence of this support appears to be leading to suboptimal results as far as quality of works is concerned. Since 6 per cent of the expenditure could be used for administrative and capacity-building purposes, resources may not be a constraint. Furthermore, the shortage of technical staff, their workload, multiple responsibilities of staff, training, delays in appointments and incentive structures are some of the human resource issues that need immediate attention, as was particularly observed from the lacunae in scheme implementation in all the states, and more so in Bihar.

\subsection{Payment agencies}

Separation of the function of wage payment from the NREG implementing agencies was conceived as a measure to avoid the misappropriation of wage payments. Almost all households surveyed in Andhra Pradesh and Rajasthan had individual post office or bank accounts through which they were paid NREGS wages. However, in Bihar, only a little more than half (52 per cent) of workers have bank accounts, indicating that payment of wages through bank or post office accounts has not yet been institutionalised. In these cases, payment in the form of daily wages was made in cash by the work supervisor who could be a ward member, rozgar sewak or the mukhiya of the Panchayat. Cash payment of daily wages is also preferred by the workers in need, but they do report underpayment and manipulations. Workers often fail to report these and instead, connive with the functionaries, who make excess entries of work on the job cards, often with the knowledge of the workers, and pocket the wages for those additional work entries. But workers' preference is for payment through the post office or a bank, if it is done within a week.

In Bihar, suggestions are made in favour of post office accounts over bank accounts for wage payments since most panchayats already have post offices, but not bank branches in their locality. There is also the fact, as observed in Gaya, that banks are not active within the NREG as they do not like to operate zero balance accounts, without receiving any commercial gain. However, it was observed in Bihar that wage payments even by post offices was fraught with some difficulties due to shortages in staff to handle the bulk of NREG payments, limited hours of operation and their having to handle other social welfare scheme-related payments, such as widows' pensions and housing assistance through Indira Awas Yojana (IAY) disbursements. 
The gap between the completion of work and payment of wages is a critical factor. The gap has been reduced substantially in Andhra Pradesh, to less than two weeks in most cases, by improved methods of IT for uplinking the logging work done and the introduction of biometric smart cards for payment (Box 5). In Rajasthan, there were immense delays in wage payments, with on average a 2-month delay (62 days) between work completion and wage payment. Moreover, in each district, almost three-quarters of the respondents reported more than a month's delay in receiving wages. Besides delays in opening accounts in the post office, where the service was very poor due to the shortage of staff and other requirements for account opening such as stationery and forms, delays in work measurements and dispatching the same to the block level are also cited as reasons for the undue gap. Additionally, in Hathela village of Tonk district, it was reported that the postmaster knowingly delayed the NREG payment and demanded money. Payment through 'minibanks' was found to be somewhat more effective in Rajasthan.

\subsection{Developing an employment calendar}

While NREG is a rights-based demand-driven programme, at the operational level the demand is influenced by the seasonality of agriculture's demand for labour. As a social protection programme, it is expected to meet the employment requirement of workers during the slack season of employment. If NREG work could meet the slack season demand, it is considered to be not only optimal but also one that avoids clash with agricultural demand for labour. Thus, there is a need to develop an NREGP calendar of works. In an exercise conducted by the Centre for Environment Concerns (CEG), an NGO in Andhra Pradesh, farmers and NREG workers were brought together to devise an agricultural employment calendar, resulting in the identification of a shelf of works, wherein small projects could be taken up any time during the year and large ones with high employment potential were slated only during the non-peak agricultural season (CEC 2009: 63-8). Such a calendar is being implemented in Andhra Pradesh and a similar approach may also be adopted by other states. Given that NREGP wages are on a par with wages in agriculture, such a seasonal calendar is expected to ensure continuous employment throughout the year for workers. Additionally, the domino effect of minimum wages offered under NREGA on agricultural wages has been welcomed for establishing a much needed wage floor for rural labour.

\section{Reflections and implications for policy 4.1 NREGP as social protection}

First and foremost, our field research informs and reconfirms the basic assumption that as a social protection programme, NREGP is able to reach the vulnerable groups as reflected in the share of employment of scheduled caste, scheduled tribes, BPL households and women. Households have also indicated reduced hunger periods and improved incomes through the NREG programme, although they are not certain about any reduction in migration. All these point towards the view that as a social protection programme, NREGP is able to address some vulnerabilities and transfer incomes to poor households. Evidence also points out that reaching such groups in a sustainable way would also require institutional structures that deliver these benefits effectively. Since the transformation of grassroots governance structures is one of the overarching objectives, such a situation would emerge only when there are processes that facilitate such a transformation. It is in this context that strengthening village-level democratic structures such as Gram Sabha and the village Panchayat, involvement of self-help groups and other autonomous collectives becomes imperative. Such processes require not only commitment of resources but also substantial attention to design aspects of NREG.

\subsection{Process and institutional improvements}

Although it was envisaged as a rights-based and demand-driven programme that is universal and self-selecting in terms of participation, the implementation of NREG, however, runs the risk of ending up like many other bureaucracy-driven public employment programmes that have been in place for many years in India. To avoid this, attention should be paid to the weaknesses of Panchayati Raj institutions at the grassroots level, which need strengthening through the provision of adequate supporting staff, capacitybuilding of both elected representatives and supporting institutions and technical assistance in preparing design of works for resource development from the village level and upwards. In the immediate future, the experience of Andhra Pradesh and Rajasthan suggest that involvement of civil society organisations, and 
proactive initiatives towards helping workers to be organised into groups to enable them with effective participation may be necessary.

Although certain pre-work processes need to be streamlined, the past experience of four years has enabled an outreach to the poor in terms of the registering and issuing of job cards. There are hardly any complaints of the exclusion of poor households from job cards, although there are instances of cards being given to the household instead of each individual worker. The demand for work through proper application could be improved by organising the workers into groups with the help of civil society

organisations. Still, the demand for work would increase with proactive initiatives on the supply side by creating a shelf of projects and publicising the availability of work continuously, so that the workers are assured that NREG work is not of short duration and sporadic in nature the reasons for relatively low demand in many instances. Regarding the worksite facilities, the basic problem appears to be insensitivity of functionaries, rather than resource constraints. Here again, proactive action by programme agencies in, e.g. supplying the right type of vessels for drinking water; budgeting in work for a person to supply water; supply and insistence on the use of first aid boxes and shelter sheets at the worksite, should be made compulsory.

While there are deficiencies in some entitlements, the most important successful one has been the provision of at least 75-100 days of work, as promised, to at least half of the participating households in Andhra Pradesh and Rajasthan (although Bihar still remains nowhere near this achievement). In most cases, the payment of statutory minimum wages is also

\section{Notes}

1 The acronyms NREG, NREGS, NREGP are used interchangeably in the literature, all meaning the National Rural Employment Guarantee Programme. We use NREG referring to the Scheme. It has been renamed recently as Mahatma Gandhi National Rural Employment Guarantee (MGNREGA). The programme came into existence through the National Rural Employment Guarantee Act (NREGA) of Parliament in February, 2006. In Phase I it was introduced in 200 of the most occurring (with the exception of delays in Rajasthan), and wages are reaching those workers who have worked under NREG. Systems related to this aspect of the programme still have teething problems, especially in Bihar, in terms of inadequate capacities of banks and post offices, although there is gradual movement towards post offices or banks in most of the cases. The Andhra Pradesh experience of biometric smart cards for payment is translated into a technology that can be adopted everywhere. Besides reducing delays, it also eliminated scope for impersonation. Another important measure that is adopted by Andhra Pradesh is the computerised uplinking of muster rolls data on days of work done and the wages due within three days of its completion. Adoption of this system would considerably reduce delays in payment of wages.

The other important aspect of the programme is the type and quality of works created and their contribution to the rural economy. While feedback is positive overall regarding the types of works, there appears to be little focus on the quality of assets due to inadequate technical capacities at the field level in terms of providing design and technical inputs while executing the works. Interactions with the field functionaries revealed this critical gap. Furthermore, consensus-based decision-making regarding the selection of assets to reflect local development has a long way to go. While it has undoubtedly emerged that the NREG has served the function of an 'employer of last resort', acting as an 'automatic stabiliser' with the demand-based nature of work cushioning the adverse impacts, the verdict is still inconclusive as to its long-term potential for promoting secure and sustainable rural livelihoods.

backward districts of the country, and an additional 130 districts were included in Phase II, in 2007-2008. The Scheme was further extended to all the remaining rural districts of India from 1 April 2008.

2 For further elaboration, see IHD (2009a,b).

3 National level secondary data also reflect similar features vis-a-vis participants of the NREG programme.

4 Others include silt application, percolation tanks, earthen bunding, etc. 


\section{References}

Aiyar, Yamini and Samji, Salimah (2009) Transparency and Accountability in NREGA - A Case Study of Andhra Pradesh, Working Paper 1, New Delhi: Accountability Initiative

Bhaduri, Amit (2005) Development with Dignity, New Delhi: National Book Trust

CEC (2009) Delivering NREGS - Challenges and Opportunities, Hyderabad: Centre for Environment Concerns

CSE (2008) NREGA - Opportunities and Challenges, Policy Paper, New Delhi: Centre for Science and Environment

IHD (2009a) 'Institutional and Governance Challenges in Social Protection: Designing Implementation Models for the Right to Work Programme in India', Working Paper submitted under the Social Protection in Asia programme, New Delhi: Institute for Human Development

IHD (2009b) 'National Rural Employment Guarantee: Issues, Concerns and Prospects', mimeo, New Delhi: Institute for Human Development

IHD (2008) Processes, Institutions and Mechanisms of Implementation of NREGA: Impact Assessment of Bihar and Jharkhand, New Delhi: Institute for Human Development

Khera, Reetika (2008) 'Group Measurement of NREGA Work: The Jalore Experiment Rajasthan - Jalore District', paper presented at 'NREGA: Impacts and Implementation Experiences', Institute for Human Development (IHD), New Delhi, 16 and 17 September
NCEUS (2009) 'Public Employment Programme (NREGA) Work for the Unorganised Workers: The Case of NREGA', The Challenge of Employment in India - An Informal Economy Perspective, New Delhi: National Commission for Enterprises in the Unorganized Sector Ngo, Thi Minh-Phuong (2010) 'Note on NREGA's Management and Information System (MIS)', seminar on Recent Evidence, Unresolved Issues and Possible Innovations, Allahabad University, 6 and 7 March

Pankaj, Ashok and Tankha, Rukmini (2009) Womens' Empowerment Through Guaranteed Employment: A Case Study of NREGA Implementation Bihar, Jharkhand, Rajasthan and Himachal Pradesh, sponsored by UNIFEM, IHD, New Delhi: Institute for Human Development Rajsekhar, B. (2009) 'Transparency and Accountability Initiatives - The Social Audit Experience in Andhra Pradesh', workshop on National Rural Employment Guarantee in India - Lessons from Implementation, Institute for Human Development and Institute of Social Studies Trust, Bangalore

Shah, Mihir (2009a) 'Inaugural Address', given at the National Seminar, National Rural Employment Guarantee in India, Institute for Human Development and Institute of Social Studies Trust, Bangalore, 8 and 9 September Shah, Mihir (2009b) 'Multiplier Accelerator Synergy in NREGA', The Hindu, 30 April

Shah, Mihir (2009c) 'Taking Goals of NREGA I Forward', The Hindu, 14 August, www.nrega.nic.in (accessed 24 February 2010) 